\title{
PERSEPSI LANSIA TERHADAP ASUHAN KEPERAWATAN GERONTIK YANG DILAKUKAN OLEH MAHASISWA FAKULTAS ILMU EPERAWATAN UNIVERSITAS INDONESIA DI KELURAHAN RAWA BUNGA KECAMATAN JATINEGARA, JAKARTA TIMUR
}

Henny Permatasari

\begin{abstract}
Abstrak
Penelitian ini bertujuan untuk mengidentifikasi sejauh mana persepsi lansia terhadap asuhan keperawatan gerontik yang diberikan oleh mahasiswa FIK-UI di Kelurahan Rawa Bunga Kecamatan Jatinegara Jakarta Timur. Metoda yang digunakn adalah deskriptif eksploratif. Sampel yang diambil sebagai responden adalah lansia yang telah dibina mahasiswa pada saat melakukan praktek keperawatan gerontik. Hasil dari penelitian ini menunjukkan bahwa lansia dapat merasakan manfaat dilakukannya asuhan keperawatan gerontik dengan skor rata-rata 4,04. Untuk menindaklanjuti penelitian ini direkomendasikan untuk melakukan penelitian tentang lansia terhadap asuhan keperawatan gerontik dengan menggunakan metode kualitatif, karena persepsi merupakan penjelasan tentang pengalaman yang perlu dipelajari secra lebih mendalam sehingga tidak cukup hanya menggunakan metode kuantitatif.
\end{abstract}

Kata kunci: lansia, metoda kuantitatif, gerontik, respon keluarga, asuhan keperawatan

\begin{abstract}
The purpose of this research was to identify how to elderly perception of the nursing care of elderly that was given by the students of Faculty of Nursing University of Indonesia. The area of this research was in 3 sub districts of Rawa Bunga district, East Jakarta. The research utilized explorative of descriptive design. Sample that was taken as the respondent were elderlies who have been cared by the student while they do their gerontological clinical practice. The result of this research showed that elderlies got the benefit from gerontic from gerontic nursing care by score 4,04. This research recommend to conduct the same research using qualitative method to gain more information related to perception and experience of elderlies.
\end{abstract}

Key word: elderly, quantitative method gerontic, family respon, nursing care. 